\title{
Educational intervention approaches to ameliorate adverse public health and environmental effects from global warming
}

\author{
Steven S. Coughlin* \\ 1029 Piedmont Avenue, no. 402, Atlanta, Georgia 30309, USA
}

In recent decades, there has been increasing scientific and public concern over global warming, a trend toward increasing temperatures in the earth's atmosphere and oceans (McCarthy et al. 2001, Patz et al. 2005, US Environmental Protection Agency [US-EPA] 2006). Most of the warming observed in recent decades is likely due to human activities such as the increased volume of carbon dioxide released by the burning of fossil fuels (Crowley 2000, McCarthy et al. 2001, USEPA 2006). The threats of changing climate conditions to human health include the following: increased risk of deaths from flooding (Christensen \& Christensen 2003); violent storms (Hoyos et al. 2006, Vecchi et al. 2006); persistent heat waves (Meehl \& Tebaldi 2004); droughts, desertification and crop failures (e.g. Stige et al. 2006); and changes in the latitudinal distribution of vector-borne diseases such as malaria and dengue fever, malnutrition and incidence of diarrheal diseases (e.g. McCarthy et al. 2001). The World Health Organization has estimated that at least 150000 deaths each year are currently directly attributable to the effects of climate disruption and that the risk will rise substantially over the next 25 yr (Patz et al. 2005).

Climate change may affect air quality and exposure to air pollutants that may aggravate chronic respiratory and cardiovascular diseases (Bernard et al. 2001, Sunyer \& Grimalt 2006). Health will also be affected indirectly by climate-induced changes in agriculture, water resources, forests, wildlife and coastal areas (US-EPA 2006).

Recent scientific evidence shows that widespread climate changes have occurred with remarkable speed and that more changes are likely in the future (McCarthy et al. 2001, Bondevik et al. 2006, Schaefer et al. 2006, US-EPA 2006). Complex systems like the atmosphere and ocean currents may move from one steady state to another when they cross a threshold (e.g. Schaefer et al. 2006). Increasing atmospheric concentrations of greenhouse gases will accelerate adverse changes in climate (US-EPA 2006). The United Nations Intergovernmental Panel on Climate Change (IPCC) is in the process of editing its newest report on climate change. Reports indicate that the new IPCC study predicts an increase of $3^{\circ} \mathrm{C}$ by 2050 (Henderson 2006). Scientists at the US-EPA predict that this degree of warming will lead to a decline in soil moisture in many regions and rises of sea level (US-EPA 2006).

The IPCC (McCarthy et al. 2001) has predicted a sea level rise of less than $1 \mathrm{~m}$ through 2100, although other estimates have been greater. More recent data on the rate ice sheets are melting worldwide indicate that by 2036, sea levels may be rising at a rate of $0.05 \mathrm{~m} \mathrm{yr}^{-1}$ or $1.0 \mathrm{~m}$ every $20 \mathrm{yr}$ (Cabanes et al. 2001, Rignot et al. 2003, Rignot \& Kanagaratnam 2006). Even modest rises in sea level would make some densely populated coastal areas uninhabitable.

The global ethical challenges posed by these developments are enormous and include the observation that the people least likely to be responsible for greenhouse gases (e.g. people in parts of Africa, Asia, and Oceania) are also those most likely to be adversely affected by global warming (McCarthy et al. 2001). Emissions from developed countries and developing countries such as China and India contribute greatly to the global production of greenhouse gases. Possible strategies for reducing the impact of global warming include the development of new technologies, the use of renewable or alternative energy sources (e.g. photovoltaic, geothermal, and wind power generation), and energy conservation. Financial incentives, such as tax deductions, grants and rebates, have been adopted in 
some countries to encourage energy conservation by individuals. Could more be done to combat global warming by encouraging the use of renewable energy sources and conservation of energy?

Educational approaches such as mass media and provision of feedback have been used to encourage individuals to adopt positive behaviors, such as energy conservation (McCalley \& Midden 1998), and have been shown to be effective for behavior modification and for encouraging appropriate decisions. Such approaches are designed to persuade individuals to take personal steps to conserve energy or to use renewable or alternative energy sources (Dietz \& Stern 2002). The content of media messages can include promotion of positive social norms. Mass media campaigns are most likely to change behaviors when they are reinforced by other efforts (e.g. Guide to Community Preventive Services; available at www.thecommunityguide.org). Reinforcing factors may include other educational interventions (e.g. small group education, assessment and feedback), grassroots activities, political action, and policy changes. Comparing performance to a goal or past behavior ('benchmarking') can be used to assess educational interventions. Interventions that include feedback are based on the premise that the provision of information about recentpast behaviors will motivate persons to adopt positive future practices (e.g. Guide to Community Preventive Services).

In the USA and other countries, members of households have received information about practical measures for energy conservation (such as home insulation and resetting thermostats) in their monthly energy bill. Information about energy efficient hybrid automobiles and gas mileage has also been provided to consumers. Consumers could be provided with more information about the amount of energy they are consuming and helpful tips about how they can conserve energy. Although privacy and confidentiality concerns must be taken into account in developing new information systems to promote energy conservation, the information and computer technology currently exist to provide consumers with printed or on-line feedback about their use of renewable or alternative energy (Dietz \& Stern 2002).

Although collective efforts to reduce greenhouse emissions such as striving to develop new technologies and alternative energy sources are reasons for optimism, ameliorating the effects of global warming will also require continued and improved efforts to educate consumers and members of the general public. More research is needed to identify effective educational intervention approaches for addressing public health and environmental affects from global warming.

Editorial responsibility: Brian M. Marcotte (Editor-in-Chief), Portland, Maine, USA

\section{LITERATURE CITED}

Bernard SM, Samet JM, Grambsch A, Ebi KL, Romieu I (2001) The potential impacts of climate variability and change on air pollution-related health effects in the United States. Environ Health Perspect 109(Suppl 2):199-209

Bondevik S, Mangerud J, Birks HH, Gulliksen S, Reimer P (2006) Changes in North Atlantic radiocarbon reservoir age during the Allerød and Younger Dryas. Science 312: $1514-1517$

Cabanes C, Cazenave A, Le Provost C. (2001) Sea level rise during past 40 years determined from satellite and in situ observations. Science 942:840-842

Christensen JH, Christensen OB (2003) Climate modeling: severe summertime flooding in Europe. Nature 421: 805-806

Crowley TJ (2000) Causes of climate change over the past 1000 years. Science 289:270-277

Dietz T, Stern PC (eds) (2002) New tools for environmental protection. Education, information, and voluntary measures. National Academy Press, Washington, DC

Henderson M (2006) Warming threatens famine, drought. Available at: www.climateark.org/articles/reader.asp? linkid $=55951$

Hoyos CD, Agudelo PA, Webster PJ, Curry JA (2006) Deconvolution of the factors contributing to the increase in global hurricane intensity. Science 312:94-97

McCalley L, Midden C (1998) Computer based systems in household appliances: the study of eco-feedback as a tool for increasing conservation behavior. Third Asian Pacific Computer and Human Interaction

McCarthy JJ, Canziani OF, Leary NA, Dokken DJ, White KS (eds) (2001) Climate change 2001: impacts, adaptation, and vulnerability. United Nations Intergovernmental Panel on Climate Change. Available at: www.grida.no/climate/ipcc_tar/wg2/001.htm

Meehl GA, Tebaldi C (2004) More intense, more frequent and longer lasting heat waves in the 21 st century. Science 305:994-997

Patz JA, Campbell-Lendrum D, Hollowway T, Foley JA (2005) Impact of regional climate change on human health. Nature 438:310-317

Rignot E, Kanagaratnam P (2006) Changes in the velocity structure of the Greenland Ice Sheet. Science 311:986-990

Rignot E, Rivera A, Casassa G (2003) Contribution of the Patagonia ice fields of South America to sea level rise. Science 302:434-437

Schaefer JM, Denton GH, Barrell DJA, Ivy-Ochs S and 5 others (2006) Near-synchronous interhemispheric termination of the last glacial maximum in mid-latitudes. Science 312:1510-1513

Stige LC, Stave J, Chan KS, Ciannelli L, Pettorelli N, Glantz M, Herren HR, Stenseth NC (2006) The effect of climate variation on agro-pastoral production in Africa. Proc Natl Acad Sci 103:3009-3010

Sunyer J, Grimalt J (2006) Global climate change, widening health inequalities, and epidemiology. Int $\mathrm{J}$ Epidemiol 35:213-216

US-EPA (2006) Global warming. US Environmental Protection Agency. Available at: http://yosemite.epa.gov/oar/ globalwarming.nsf/content/index.html

Vecchi GA, Soden BJ, Wittenberg AT, Held IM, Leetmaa A, Harrison MJ (2006) Weakening of tropical Pacific atmospheric circulation due to anthropogenic forcing. Nature 441:73-76

Submitted: May 13, 2006; Accepted: July 3, 2006

Proofs received from author(s): July 13, 2006

Published on the web: July 14, 2006 